\title{
EMPLOYEE SATISFACTION WITH THE EMPLOYER'S HEALTH SAFETY ACTIVITIES DURING THE SARS-COV-2 PANDEMIC
}

doi: $10.2478 /$ czoto-2021-0023

Date of submission of the article to the Editor: 06/12/2020

Date of acceptance of the article by the Editor: 31/03/2021

Katarzyna Zadros ${ }^{1}$ - orcid id: 0000-0003-4130-5567

Abstract: The outbreak of the SARS-CoV-2 coronavirus pandemic has resulted in significant changes in employers' attitudes to employee health safety, as a new rapidly spreading threat has emerged. A characteristic feature of this threat is very little knowledge about it and the lack of effective treatments and prevention procedures. The short time since the outbreak of the pandemic also means that there is very little knowledge about how employers try to protect employees from infection with this virus, as well as how effective these actions are and how employees evaluate them. Therefore, among couriers of UPS companies in Poland and Germany a survey of the satisfaction was undertaken regarding the solutions adopted and implemented by managers in the field of shaping the health safety of employees. The survey uses the modified Customer Satisfaction Index - CSI method, for which employees were treated as internal customers. As a result of the research, it was possible to compare employee satisfaction with the solutions used by managers to protect their health in Poland and Germany, and shape conclusions resulting from this study.

Keywords: pandemic SARS-CoV-2 (COVID-19), modified CSI method, couriers, Poland, Germany

\section{INTRODUCTION}

The courier industry is one of the fastest developed in latest years in whole Europe. It is also one of few which in 2020 did not suffer losses as a consequence of market change situation effected by pandemic SARS-CoV-2 and lockdown or significant traditional trade reduction caused by it. Even more the participation in market highly increased. There has also been a significant increase in the demand for employees, including couriers, who at the time of the closure of other areas of the economy, work as they would normally do in the courier industry at around Christmas (Gruenwald, 2020)). It is observed that the increasing demand of courier service is connected with individuals, the deliveries to the flats and houses as individual services as result the necessity of contact with large number of people. In turn, the demand of commerce service is decreasing due to closure of many industries and companies (Baryshnikova, et al. 2021; Ingaldi and Ulewicz, 2019; Wood, 2020). As a result, despite the couriers more effective work, the companies' profits have not increased or even decreased in 
first quarters of pandemic. This was due not only to a decrease in the number of commercial services, but also an increase in costs caused by additional sanitary restrictions (FedEx..., 2020). It could therefore be assumed that increased volume of work and time consuming connected with it, the salaries and other elements of couriers' work motivation have not changed. Whereas the risk of the work performance and generated infection of coronavirus has increased. Apparently, the work which has been looked the same is totally different. Especially, as a part of struggling with pandemic, the companies have been obligated to launched several restrictions and limitations (COVID-19..., 2020; Duszyński et al., 2020) which generates adverse change in couriers' work conditions. It influenced on their attitude to the occupation and work satisfaction level which might be determined by other factors than before the pandemic. It seems to be significant the statement, that launched in companies restrictions minimalize the infection of COVID-19 and influence on work satisfaction. This is because, the lack of satisfaction from the implemented rules could be not obey, and at the same increase the epidemic risk.

Described above the couriers' industry and also the couriers' work changes present that current knowledge about the work condition and satisfaction of those ones is partially not up to date. In one hand, the new conditions of service causes with pandemic and necessity of protection the couriers from the infection of COVID-19, in the other hand, the obstacles with work performance fully determine taking the issue of empirical research, what did the author of this article.

\section{METHODOLOGY OF RESEARCH}

The method on which the research of couriers' opinion gathered was the modified Customer Satisfaction Index-CSI which is used mainly in quality service research and also it is a source of knowledge in marketing strategy creation (Woźniak and Zimoń, 2013). It should be noted that the application of this method to employees was based on the assumption that they are internal customers of the company (Huang, 2020), so it is possible to examine them using the same methods as for external customers carried out as part of marketing research.

For the research it was used the questionnaire, which the analysis was based on the weighted evaluation. The result was consisted of the assessment of the respondents using the groups of factors and the weights assigned to them (Woźniak, 2017). By the questionnaire was evaluated the satisfaction from the implemented rules which prevent the infection of coronavirus, which factors were determined in the list of control questions regarding the safety and health protection of people who worked during the pandemic of Covid-19 were based on OSHA-EU regulations (Bezpieczeństwo..., 2020). In the research was gathered the opinion regarding the safety area, which determines the list: the prevent action planning of Covid-10 infection, the distance area assurance, required direct contact work performance, obey the workplace hygiene rules, the personal protection measures and working clothing assurance, limitation of mental strain caused by pandemic and communicating in connection with it and also the procedures in case of the infection of SARS-COV-2 .

The responders (couriers) - 167 who work in Polish departments of UPS and 83 in German - assessed the level of satisfaction and each factor of research area in grade of 1 to 5 (Likert's grade) (Turkyilmaz et al., 2013; Minata and Cempiel, 2017), where the satisfaction was determined: 1 - very dissatisfied, 2 - rather dissatisfied, 3 - neutral, 4 - rather satisfied, 5 - very satisfied. Whereas the determination of significance (rank) 
of each factor for the responders: 1 - not important, 2 - lack of importance, 3 - neutral, 4 - important, 5 - very important.

The grade was used with the questionnaire and counting determination of the satisfaction level. The substantive questions regarding the satisfaction was complemented by metrics, thanks to them it was possible to characterise and compare of both trials. It should be noted, that selection of the responders was random, and the trial was uncommon thus the research results are not representative.

\section{RESULTS}

Prepared for the article's needs the research was determined via Intranet in 12 departments of UPS in Poland and 5 in Germany in period from: 1.12-10.12.2020. The correct and completed questionnaires were filled by 167 Polish and 83 Germans couriers. Based on their matric data the demographic characteristic was provided - Table 1. However, their evaluation of satisfaction and significance of the implemented by the management solution to protect them from Covid-19, helps to analyse that significance and compare the results for Polish and German couriers- table 2 and 3.

Table 1

Demographic characteristics of the respondents

\begin{tabular}{|c|c|c|c|c|c|}
\hline \multirow{2}{*}{\multicolumn{2}{|c|}{ nationality }} & \multicolumn{2}{|c|}{ PL } & \multicolumn{2}{|c|}{ GER } \\
\hline & & \multirow{2}{*}{$\begin{array}{c}\begin{array}{c}\text { number of } \\
\text { indications }\end{array} \\
4\end{array}$} & $\%$ & $\begin{array}{c}\text { number of } \\
\text { indications }\end{array}$ & $\%$ \\
\hline \multirow{2}{*}{ sex } & woman & & 2.4 & 0 & 0 \\
\hline & man & 163 & 97.6 & 83 & 100 \\
\hline \multicolumn{2}{|l|}{$\bar{\Sigma}$} & 167 & 100 & 83 & 100 \\
\hline \multirow{6}{*}{ age } & do 20 years & 3 & 1.8 & 8 & 9.6 \\
\hline & $21-30$ years & 67 & 40.1 & 69 & 83.1 \\
\hline & $31-40$ years & 72 & 43.1 & 6 & 7.3 \\
\hline & $41-50$ years & 22 & 13.2 & 0 & 0 \\
\hline & $51-60$ years & 3 & 1.8 & 0 & 0 \\
\hline & $\geq 61$ years & 0 & 0 & 0 & 0 \\
\hline \multicolumn{2}{|l|}{$\Sigma$} & 167 & 100 & 83 & 100 \\
\hline \multicolumn{2}{|l|}{$\overline{\mathbf{x}}$} & 30.6 & - & 24.9 & - \\
\hline \multirow{4}{*}{ education } & professional & 3 & 1.8 & 30 & 36.1 \\
\hline & medium & 75 & 44.9 & 52 & 62.7 \\
\hline & higher $I^{\circ}$ & 58 & 34.7 & 1 & 1.2 \\
\hline & higher $I^{\circ}$ & 31 & 18.6 & 0 & 0 \\
\hline \multicolumn{2}{|l|}{$\Sigma$} & 167 & 100 & 83 & 100 \\
\hline \multirow{6}{*}{$\begin{array}{l}\text { seniority } \\
\text { in } \\
\text { company }\end{array}$} & $1-2$ years & 40 & 23.9 & 7 & 8.4 \\
\hline & 3-5 years & 92 & 55.1 & 71 & 85.6 \\
\hline & $6-10$ years & 25 & 15 & 3 & 3.6 \\
\hline & $11-15$ years & 6 & 3.6 & 1 & 1.2 \\
\hline & $16-20$ years & 4 & 2.4 & 1 & 1.2 \\
\hline & $\geq 20$ years & 0 & 0 & 0 & 0 \\
\hline \multicolumn{2}{|l|}{$\bar{\Sigma}$} & 167 & 100 & 83 & 100 \\
\hline \multicolumn{2}{|l|}{$\overline{\mathbf{x}}$} & 3.7 & - & 4 & - \\
\hline \multirow{3}{*}{$\begin{array}{l}\text { number of } \\
\text { jobs }\end{array}$} & 1 & 59 & 35.3 & 81 & 97.6 \\
\hline & $2-3$ & 72 & 43.1 & 2 & 2.4 \\
\hline & $4-5$ & 26 & - & 0 & 0 \\
\hline
\end{tabular}




\begin{tabular}{|l|l|l|l|l|l|}
\hline & $\geq 6$ & 10 & - & 0 & 0 \\
\hline$\Sigma$ & 167 & $\mathbf{1 0 0}$ & $\mathbf{8 3}$ & $\mathbf{1 0 0}$ \\
\hline$\overline{\mathbf{x}}$ & $\mathbf{2 . 5}$ & - & $\mathbf{1}$ & \\
\hline
\end{tabular}

Source: own study based on a questionnaire survey

Comparing the responders' demographic characteristics, we can assume that in a trial dominating group were men, only among Polish couriers were few women- $2,4 \%$. Next characteristic which might describe the responders is their age. Both groups were dominated by proportionally young people. The average age of Polish couriers was 30,6 years old and Germans even lower- 24,9 years old. There were hardly any person above 50 years old, only in Polish group 3 people exceeded this age limit.

The significant differences were visible in the educational level of the responders, in Polish group majority people have a higher education level $1^{\text {st }}$ or $2^{\text {nd }}$ degree (B.A. or M.A. degree), while the largest group of German responders have secondary education.

Analogously to the age, the work experience in company was relatively short, for Polish responders was 3,7 years and for Germans was slightly more, 4years. It should be noted that both groups are dominated by people with relatively short work experience in the company, only 4 Polish responders and 1 German indicated the time of work in the company exceeding 15 years.

Due to the fact that statistical Polish responder studied a several years longer, the difference between the work experience is obviously. It should also be noted that the slightly longer seniority in the company may also be due to the fact that Polish couriers changed jobs in contrast to German couriers. For more than $97 \%$ of them UPS was their first job, while a statistical Poles had already changed their job 2.5 times.

To summarize, a typical survey participant was a young, male, in case of German with secondary education and about 4 years seniority in UPS, while Pole was most likely to have a higher education, had a little over 3.5 years seniority in UPS, and the company was the second or third workplace.

A comparison of satisfaction with a workplace health and safety management in connection with pandemic of Covid-19 in the international branches which are operating in the EU it is possible by the fact, that restriction implemented in European countries are unified by OSHA-UE (Bezpieczeństwo..., 2020). Therefore, it was decided to conduct such a study, based on an identical tool, in UPS Poland and UPS Germany. The result of this study is shown in the presented elaboration.

The evaluation of work condition satisfaction, which have been assure for couriers by Polish And German managers differ significantly. For better evidence of those difference, in table the lowest average values were highlighted and underlined and the highest were highlighted only.

It is clearly visible the much lower satisfaction level of Poles. What is important, the rank of each evaluated action in Polish responders have less important assessment.

This probably means that this evaluation must also have been influenced by satisfaction factors from other areas than those covered by this survey. In the group of German respondents, ratings were much higher and it was evident that respondents were paid more attention to them. It may be assumed that in this group, factors not included in the survey did not influence on the survey area ratings as much.

Evaluating the final level of satisfaction with the management's activity regarding the protection against the infection in both groups are visible that Poles couriers evaluated 
the implemented by the company rules slightly below the average value -2.9 and Germans significantly higher - 3.7. According to Poles, the lowest rate of their satisfaction was related to cleaning and washing of working clothing, while in Germans the parcels disinfection. On the other hand, the highest rated actions were: for Poles the access to disinfectants ensure by company - average score of 3.86 , and for Germans - a quality of personal protective equipment provided by the company average score of 4.33 .

Table 2

Level of satisfaction with protection against Covid-19 infection

\begin{tabular}{|c|c|c|c|c|c|c|c|c|c|c|c|c|}
\hline \multirow{3}{*}{ FACTOR } & \multicolumn{12}{|c|}{ SATISFACTION LEVEL } \\
\hline & \multicolumn{2}{|c|}{1} & \multicolumn{2}{|c|}{2} & \multicolumn{2}{|c|}{3} & \multicolumn{2}{|c|}{4} & \multicolumn{2}{|c|}{5} & \multicolumn{2}{|c|}{$\overline{\mathbf{x}}$} \\
\hline & PL & $\mathbf{G}$ & PL & $G$ & $\mathbf{P L}$ & $\mathbf{G}$ & PL & G & PL & $G$ & PL & G \\
\hline $\begin{array}{l}\text { developing a } \\
\text { plan to deal } \\
\text { with Covid }\end{array}$ & 3 & 2 & 19 & 4 & 117 & 51 & 22 & 19 & 6 & 7 & 3.05 & 3.25 \\
\hline $\begin{array}{l}\text { implementation } \\
\text { of a Covid } \\
\text { management } \\
\text { plan }\end{array}$ & 4 & 2 & 16 & 9 & 119 & 34 & 22 & 21 & 3 & 17 & 2.91 & 3.51 \\
\hline $\begin{array}{l}\text { adoption of } \\
\text { epidemic } \\
\text { procedures }\end{array}$ & 12 & 2 & 38 & 7 & 96 & 30 & 16 & 25 & 5 & 19 & 2.78 & 3.63 \\
\hline $\begin{array}{l}\text { implementation } \\
\text { of preventive } \\
\text { measures }\end{array}$ & 11 & 3 & 17 & 11 & 106 & 25 & 20 & 26 & 13 & 18 & 3.04 & 3.54 \\
\hline $\begin{array}{l}\text { implementation } \\
\text { of individual } \\
\text { protective } \\
\text { measures }\end{array}$ & 38 & 2 & 51 & 8 & 52 & 23 & 18 & 29 & 8 & 21 & 2.5 & 3.71 \\
\hline $\begin{array}{l}\text { training } \\
\text { couriers in this } \\
\text { area }\end{array}$ & 18 & 8 & 32 & 9 & 94 & 28 & 19 & 26 & 4 & 12 & 2.75 & 3.3 \\
\hline $\begin{array}{l}\text { provision of } \\
\text { personal } \\
\text { protective } \\
\text { equipment }\end{array}$ & 5 & 5 & 24 & 12 & 58 & 18 & 61 & 29 & 19 & 19 & 3.39 & 3.54 \\
\hline $\begin{array}{l}\text { creating safe } \\
\text { working } \\
\text { conditions }\end{array}$ & 12 & 1 & 19 & 6 & 77 & 24 & 48 & 31 & 11 & 21 & 3.16 & 3.78 \\
\hline $\begin{array}{l}\text { defining the } \\
\text { principles of } \\
\text { health } \\
\text { monitoring }\end{array}$ & 19 & 2 & 27 & 7 & 89 & 23 & 23 & 36 & 9 & 15 & 2.86 & 3.66 \\
\hline $\begin{array}{l}\text { practical } \\
\text { application of } \\
\text { health control } \\
\text { principles }\end{array}$ & 7 & 2 & 72 & 9 & 53 & 20 & 28 & 39 & 7 & 13 & 2.74 & 3.63 \\
\hline $\begin{array}{l}\text { equipment } \\
\text { disinfection }\end{array}$ & 28 & 1 & 53 & 7 & 63 & 8 & 19 & 45 & 4 & 22 & 2.51 & 3.96 \\
\hline $\begin{array}{l}\text { vehicle } \\
\text { disinfection }\end{array}$ & 35 & 0 & 81 & 8 & 28 & 7 & 17 & 44 & 6 & 24 & 2.27 & 4.01 \\
\hline
\end{tabular}




\begin{tabular}{|c|c|c|c|c|c|c|c|c|c|c|c|c|}
\hline $\begin{array}{l}\text { limiting the } \\
\text { time of contact } \\
\text { with other } \\
\text { employees }\end{array}$ & 22 & 6 & 28 & 11 & 47 & 25 & 53 & 29 & 17 & 12 & 3.09 & 3.36 \\
\hline $\begin{array}{l}\text { limiting the } \\
\text { time of contact } \\
\text { with customers }\end{array}$ & 9 & 2 & 19 & 6 & 8 & 19 & 92 & 32 & 39 & 24 & 3.8 & 3.84 \\
\hline $\begin{array}{l}\text { availability of } \\
\text { disinfectants }\end{array}$ & 7 & 1 & 12 & 5 & 16 & 9 & 95 & 39 & 37 & 29 & 3.86 & 4.08 \\
\hline $\begin{array}{l}\text { quantitative } \\
\text { protection of } \\
\text { personal } \\
\text { protective } \\
\text { equipment }\end{array}$ & 11 & 0 & 19 & 4 & 20 & 11 & 86 & 37 & 31 & 31 & 3.64 & 4.14 \\
\hline $\begin{array}{l}\text { security } \\
\text { qualitative } \\
\text { personal } \\
\text { protective } \\
\text { equipment }\end{array}$ & 14 & 1 & 26 & 3 & 46 & 0 & 58 & 43 & 23 & 36 & 3.3 & 4.33 \\
\hline $\begin{array}{l}\text { storage of } \\
\text { used personal } \\
\text { protective } \\
\text { equipment }\end{array}$ & 29 & 3 & 46 & 9 & 25 & 10 & 41 & 38 & 26 & 23 & 2.93 & 3.83 \\
\hline $\begin{array}{l}\text { disposal of } \\
\text { used personal } \\
\text { protective } \\
\text { equipment }\end{array}$ & 5 & 1 & 62 & 6 & 59 & 16 & 32 & 39 & 9 & 21 & 2.87 & 3.88 \\
\hline $\begin{array}{l}\text { security of } \\
\text { shipments }\end{array}$ & 9 & 2 & 21 & 3 & 46 & 51 & 72 & 20 & 19 & 7 & 3.43 & 3.33 \\
\hline $\begin{array}{l}\text { disinfection of } \\
\text { shipments }\end{array}$ & 13 & 4 & 26 & 15 & 59 & 39 & 52 & 17 & 17 & 8 & 3.2 & $\underline{3.12}$ \\
\hline $\begin{array}{l}\text { security of } \\
\text { work clothing } \\
\text { storage }\end{array}$ & 41 & 2 & 66 & 8 & 48 & 42 & 9 & 19 & 3 & 12 & 2.2 & 3.37 \\
\hline $\begin{array}{l}\text { safe use of } \\
\text { work clothes }\end{array}$ & 42 & 4 & 58 & 12 & 51 & 30 & 12 & 23 & 4 & 14 & 2.27 & 3.37 \\
\hline $\begin{array}{l}\text { no contact } \\
\text { between work } \\
\text { and private } \\
\text { clothing }\end{array}$ & 43 & 5 & 69 & 17 & 46 & 19 & 7 & 31 & 2 & 11 & 2.07 & 3.31 \\
\hline $\begin{array}{l}\text { cleaning and } \\
\text { washing of } \\
\text { work clothes }\end{array}$ & 58 & 2 & 72 & 3 & 31 & 17 & 4 & 42 & 2 & 19 & 1.92 & 3.88 \\
\hline $\begin{array}{l}\text { flexible } \\
\text { working time }\end{array}$ & 23 & 9 & 37 & 11 & 81 & 23 & 19 & 27 & 7 & 13 & 2.7 & 3.29 \\
\hline $\begin{array}{l}\text { psychologist } \\
\text { support }\end{array}$ & 9 & 5 & 11 & 8 & 130 & 19 & 12 & 32 & 5 & 19 & 2.96 & 3.63 \\
\hline $\begin{array}{l}\text { information on } \\
\text { implemented } \\
\text { security } \\
\text { measures }\end{array}$ & 8 & 4 & 21 & 6 & 108 & 13 & 19 & 29 & 11 & 31 & 3.02 & 3.93 \\
\hline $\begin{array}{l}\text { the existence } \\
\text { of a Covid } \\
\text { procedure }\end{array}$ & 8 & 2 & 27 & 2 & 112 & 17 & 11 & 36 & 9 & 26 & 2.92 & 3.99 \\
\hline
\end{tabular}




\begin{tabular}{|l|l|l|l|l|l|l|l|l|l|l|l|l|}
\hline $\begin{array}{l}\text { Compliance } \\
\text { with the } \\
\text { procedure in } \\
\text { practice }\end{array}$ & 19 & 3 & 31 & 5 & 87 & 19 & 19 & 21 & 11 & 35 & 2.83 & 3.96 \\
\hline $\mathbf{\Sigma}$ & $\mathbf{1 8 . 7}$ & $\mathbf{2 . 9}$ & $\mathbf{3 6 . 7}$ & $\mathbf{7 . 7}$ & $\mathbf{6 5 . 7}$ & $\mathbf{2 2 . 3}$ & $\mathbf{3 3 . 6}$ & $\mathbf{3 0 . 8}$ & $\mathbf{1 2 . 2}$ & $\mathbf{1 9 . 3}$ & $\mathbf{2 . 9}$ & $\mathbf{3 . 7}$ \\
\hline
\end{tabular}

Source: own study based on a questionnaire survey

Similar analogy might be observed in analysing the opinion regarding the importance of studied factors (Table 3). In the issue of importance factors in both groups are totally different and have totally different rank. For Poles the most significant is the quality of delivering the means of personal protection- average score 3.98, and for Germans- the access to disinfectants- average score 4.43. The lowest importance for responders have: determination of the health control for Polish couriers - 2.4 average score, for Germans the limitation of time with the customers- average score - 2.41.

The analysis of the existing differences in evaluation of managers' action taken might have been still pending from many other different perspectives, and could be used other statistical analysis means, pointing this crucial differences allow to conclude that such research are legitimate and should be conducted in broader scope than only for the purpose of this study.

Table 3

Importance of managers' actions to protect couriers against Covid-19 infection

\begin{tabular}{|c|c|c|c|c|c|c|c|c|c|c|c|c|}
\hline \multirow{3}{*}{ FACTOR } & \multicolumn{12}{|c|}{ IMPORTANCE } \\
\hline & \multicolumn{2}{|c|}{1} & \multicolumn{2}{|c|}{2} & \multicolumn{2}{|c|}{3} & \multicolumn{2}{|c|}{4} & \multicolumn{2}{|c|}{5} & \multicolumn{2}{|c|}{$\overline{\mathbf{x}}$} \\
\hline & PL & $\mathbf{G}$ & $\mathbf{P L}$ & $\mathbf{G}$ & $\mathbf{P L}$ & $\mathbf{G}$ & $\mathbf{P L}$ & $\mathbf{G}$ & PL & $\mathbf{G}$ & PL & $\mathbf{G}$ \\
\hline $\begin{array}{l}\text { developing a plan } \\
\text { to deal with Covid }\end{array}$ & 0 & 0 & 7 & 7 & 153 & 17 & 6 & 50 & 1 & 9 & 3 & 3.73 \\
\hline $\begin{array}{l}\text { implementation of } \\
\text { a Covid } \\
\text { management plan }\end{array}$ & 1 & 0 & 32 & 6 & 122 & 22 & 9 & 41 & 3 & 14 & 2.89 & 3.76 \\
\hline $\begin{array}{l}\text { adoption of } \\
\text { epidemic } \\
\text { procedures }\end{array}$ & 13 & 1 & 27 & 12 & 119 & 31 & 6 & 28 & 2 & 11 & 2.74 & 3.43 \\
\hline $\begin{array}{l}\text { implementation of } \\
\text { preventive } \\
\text { measures }\end{array}$ & 3 & 2 & 15 & 7 & 92 & 13 & 48 & 30 & 9 & 31 & 2.72 & 3.98 \\
\hline $\begin{array}{l}\text { implementation of } \\
\text { individual } \\
\text { protective } \\
\text { measures }\end{array}$ & 5 & 1 & 21 & 5 & 90 & 17 & 44 & 21 & 7 & 39 & 3.16 & 4.11 \\
\hline $\begin{array}{l}\text { training couriers in } \\
\text { this area }\end{array}$ & 2 & 8 & 7 & 9 & 145 & 12 & 12 & 42 & 1 & 12 & 3.02 & 3.49 \\
\hline $\begin{array}{l}\text { provision of } \\
\text { personal protective } \\
\text { equipment }\end{array}$ & 1 & 2 & 25 & 5 & 102 & 7 & 26 & 38 & 13 & 31 & 3.15 & 4.1 \\
\hline $\begin{array}{l}\text { creating safe } \\
\text { working conditions }\end{array}$ & 5 & 1 & 17 & 3 & 108 & 11 & 35 & 26 & 2 & 42 & 3.07 & 4.27 \\
\hline $\begin{array}{l}\text { defining the } \\
\text { principles of health } \\
\text { monitoring }\end{array}$ & 19 & 5 & 78 & 9 & 57 & 19 & 11 & 21 & 2 & 29 & $\underline{2.4}$ & 3.72 \\
\hline $\begin{array}{l}\text { practical } \\
\text { application of }\end{array}$ & 17 & 4 & 71 & 12 & 63 & 17 & 13 & 28 & 3 & 22 & 2.49 & 3.63 \\
\hline
\end{tabular}




\begin{tabular}{|c|c|c|c|c|c|c|c|c|c|c|c|c|}
\hline $\begin{array}{l}\text { health control } \\
\text { principles }\end{array}$ & & & & & & & & & & & & \\
\hline $\begin{array}{l}\text { equipment } \\
\text { disinfection }\end{array}$ & 10 & 6 & 18 & 9 & 85 & 21 & 39 & 20 & 15 & 27 & 3.19 & 3.64 \\
\hline vehicle disinfection & 5 & 3 & 17 & 6 & 120 & 12 & 22 & 21 & 3 & 41 & 3 & 4.1 \\
\hline $\begin{array}{l}\text { limiting the time of } \\
\text { contact with other } \\
\text { employees }\end{array}$ & 16 & 9 & 24 & 17 & 104 & 23 & 14 & 23 & 9 & 11 & 2.86 & 3.12 \\
\hline $\begin{array}{l}\text { limiting the time of } \\
\text { contact with } \\
\text { customers }\end{array}$ & 7 & 12 & 42 & 25 & 66 & 21 & 38 & 18 & 14 & 7 & 3.06 & $\underline{2.41}$ \\
\hline $\begin{array}{l}\text { availability of } \\
\text { disinfectants }\end{array}$ & 3 & 0 & 9 & 3 & 32 & 9 & 94 & 20 & 29 & 51 & 3.82 & 4.43 \\
\hline $\begin{array}{l}\text { quantitative } \\
\text { protection of } \\
\text { personal protective } \\
\text { equipment }\end{array}$ & 8 & 3 & 12 & 7 & 29 & 15 & 97 & 32 & 21 & 26 & 3.66 & 3.86 \\
\hline $\begin{array}{l}\text { security qualitative } \\
\text { personal protective } \\
\text { equipment }\end{array}$ & 3 & 2 & 9 & 5 & 17 & 9 & 97 & 18 & 41 & 49 & 3.98 & 4.29 \\
\hline $\begin{array}{l}\text { storage of used } \\
\text { personal protective } \\
\text { equipment }\end{array}$ & 5 & 5 & 11 & 11 & 15 & 23 & 97 & 18 & 39 & 26 & 3.92 & 3.47 \\
\hline $\begin{array}{l}\text { disposal of used } \\
\text { personal protective } \\
\text { equipment }\end{array}$ & 9 & 4 & 13 & 12 & 28 & 21 & 86 & 18 & 31 & 28 & 3.7 & 3.65 \\
\hline $\begin{array}{l}\text { security of } \\
\text { shipments }\end{array}$ & 2 & 9 & 19 & 23 & 13 & 27 & 88 & 15 & 45 & 9 & 3.93 & 2.66 \\
\hline $\begin{array}{l}\text { disinfection of } \\
\text { shipments }\end{array}$ & 6 & 2 & 23 & 4 & 98 & 6 & 31 & 33 & 9 & 38 & 3,08 & 4,22 \\
\hline $\begin{array}{l}\text { security of work } \\
\text { clothing storage }\end{array}$ & 25 & 1 & 27 & 5 & 103 & 14 & 11 & 32 & 1 & 31 & 2,62 & 4,05 \\
\hline $\begin{array}{l}\text { safe use of work } \\
\text { clothes }\end{array}$ & 15 & 3 & 49 & 4 & 67 & 9 & 31 & 37 & 5 & 20 & 2,77 & 3,45 \\
\hline $\begin{array}{l}\text { no contact between } \\
\text { work and private } \\
\text { clothing }\end{array}$ & 12 & 2 & 19 & 5 & 85 & 18 & 39 & 16 & 12 & 42 & 3,12 & 4,1 \\
\hline $\begin{array}{l}\text { cleaning and } \\
\text { washing of work } \\
\text { clothes }\end{array}$ & 9 & 4 & 26 & 12 & 83 & 16 & 32 & 26 & 17 & 25 & 3.13 & 3.67 \\
\hline $\begin{array}{l}\text { flexible working } \\
\text { time }\end{array}$ & 2 & 2 & 8 & 18 & 34 & 19 & 92 & 36 & 31 & 8 & 3.85 & 3.24 \\
\hline $\begin{array}{l}\text { psychologist } \\
\text { support }\end{array}$ & 9 & 5 & 17 & 11 & 131 & 22 & 8 & 17 & 2 & 28 & 2.98 & 3.63 \\
\hline $\begin{array}{l}\text { information on } \\
\text { implemented } \\
\text { security measures }\end{array}$ & 4 & 3 & 9 & 6 & 140 & 12 & 9 & 27 & 5 & 35 & 3.01 & 4.02 \\
\hline $\begin{array}{l}\text { the existence of a } \\
\text { Covid procedure }\end{array}$ & 15 & 7 & 28 & 11 & 104 & 18 & 17 & 26 & 3 & 21 & 2.79 & 3.52 \\
\hline $\begin{array}{l}\text { compliance with } \\
\text { the procedure in } \\
\text { practice }\end{array}$ & 14 & 2 & 25 & 5 & 113 & 6 & 13 & 31 & 2 & 39 & 2.78 & 4.20 \\
\hline$\Sigma$ & 8.3 & 3.6 & 23.6 & 9.1 & 84 & 15.6 & 38.4 & 27 & 12.7 & 27.7 & 2.87 & 3.73 \\
\hline
\end{tabular}

Source: own study based on a questionnaire survey 


\section{DISCUSSION}

The year 2020 brought significant changes in the research issues in all fields of science and forced the economies of countries around the world to introduce completely new management solutions in all areas of economic and socio-political life. The problem that has defined and continues to define the areas and issues of research is the SARS-CoV2 virus and the Covid-19 pandemic caused by it (Allam, 2020).

The first scientific publications on the impact of the pandemic on the functioning of enterprises and economies appeared at the end of the first and the beginning of the second quarter of this year (Gruenwald, 2020). Their issues mainly included analytical studies of the health, economic and social consequences of the pandemic. In the current scientific reports, proportionally little space has been devoted to the activities of company managers that are to guarantee the safety of employees' work, and if this issue arises, it usually concerns people working in the medical profession.

It is equally important to undertake research on other professional groups that are also exposed to pandemic threats, especially to COVID-19 infection, including couriers. The work they do requires constant contact with a large number of people. In fact, this contact is usually quite short, but intense, often associated with high physical effort and increased respiratory needs, and this promotes infections and virus transmission in the environment.

OSHA-EU, recognizing the pandemic dangers, has developed precise guidelines, addressed to all EU Member States and companies operating within it, on ensuring safety and health at work during the pandemic (COVID-19, 2020). In its recommendations, specialists tried to take into account all the risks that may arise in the new working conditions and indicate solutions to minimize these risks. Detailed regulations, created on the basis of these guidelines, are obliged to follow all companies in the EU, including courier companies. At the same time, it seems obvious that the implementation of the solutions recommended by OSHA is to, on the one hand, increase the level of health safety of employees, and, on the other hand, should contribute to building employee satisfaction with working conditions.

If employees are not satisfied with the solutions introduced by managers, they may not be complied with, and thus expose themselves (Jeevan and Jyoti, 2012; Bacotic, 2016), as well as other internal clients and external clients of the company, to the risk of disease. Therefore, the research conducted among couriers regarding their satisfaction with pandemic working conditions should be considered fully justified. At the same time, no reports on this issue were found in currently available publications. This made the author decide on this particular area of research, also deciding to use in her work the methodology used in external customer satisfaction surveys, i.e. the Customer Satisfaction Index (CSI) method (Xiaohong et al., 2008).

The conducted research allowed to state the existence of large differences in the assessment of the own satisfaction of couriers working in UPS Polska and UPS Germany. It also allowed to determine the effectiveness of the tool used.

The study shows that limiting the issue only to health safety and protection against Covid-19 infection does not allow for a fully unambiguous assessment of the level of job satisfaction, such a study should be extended to include other satisfaction and motivation factors. This, in turn, allows us to set further directions for researching the issues discussed in this article and searching for relationships between it and the broadly understood motivation to work. 


\section{CONCLUSION}

To summarize, the research results and consideration based on the subject literature analysis should be concluded, that CSI tool could be equally effective and used in satisfaction research in external and internal customers. However in case of internal customers, the study should include broader bundle of matters thus the conducting only the sector study, as it was completed for the presented article purpose above, could effect that significant for complete evaluation of satisfaction factors would be omitted. It is visible that, this kind of research could provide equally significant knowledge for management indicating the area of change in managing the human resources, which should be implemented in company as well as the researchers to develop the research tools and methods of analysing and verification with using their temporary knowledge regarding the motivation and factors which have decided of the employees' involvement and their effectiveness in work process.

It is worth to pay attention on issues concerning the possibility of comparing the management process resulting from cultural differences in the functioning not only the company but also whole society and their influence on managers actions and the way of functioning the companies in the same industry and even those which belong to the same parent company.

Finally, it also seems that undertaking a broader study of the health and epidemic safety situation of couriers, who can be considered as one of the high-risk occupational groups, is fully justified for both the theory and practice of management in terms of organisations and communities.

\section{REFERENCES}

Allam, Z., 2020. The First 50 days of COVID-19: A Detailed Chronological Timeline and Extensive Review of Literature Documenting the Pandemic, Elsevier Public Health Emergency Collection, Jul, 1-7. DOI: 10.1016/B978-0-12-824313-8.00001-2

Bacotic, D., 2016, Relationship between job satisfaction and organisational performance, Economic Research 18, 118-130. DOI: 10.1080/1331677X.2016.1163946

Baryshnikova, N., Kiriliuk, O., Klimecka-Tatar, D., 2021. Enterprises' strategies transformation in the real sector of the economy in the context of the COVID-19 pandemic, Production Engineering Archives, 27(1), 8-15. DOI: 10.30657/pea.2021.27.2

Bezpieczeństwo i ochrona zdrowia osób pracujących w czasie epidemii COVID-19, 2020. CIOP-PIB, Warszawa.

COVID-19: BACK TO THE WORKPLACE - Adapting workplaces and protecting workers, https://osha.europa.eu/en/publications/covid-19-back-workplace-adaptingworkplaces-and-protecting-workers/view (24.04.2020), 1-16.

Duszyński, J., Afelt, A., Ochab-Marcinek, A., Owczuk, R., Pyrć, K., Rosińska, M., Rychard, A., Smiatacz, T., 2020. Zrozumieć COVID-19, PAN, Warszawa, 38-41.

FedEx tries to think beyond the pandemic, The Economist 2020, July.

Gruenwald, H., 2020. Parcel Delivery Services boom during Covid-19.

https://www.economist.com/business/2020/07/02/fedex-tries-to-think-beyond-thepandemic

Huang, Y-T., 2020. Internal Marketing and Internal Customer: A Review, Reconceptualization, and Extension, Journal of Relationship Marketing, 19(3), 165181. DOI: $10.1080 / 15332667.2019 .1664873$ 
Ingaldi, M.,Ulewicz, R., 2019. How to Make E-Commerce More Successful by Use of Kano's Model to Assess Customer Satisfaction in Terms of Sustainable Development. Sustainability 11, 18, 4830. DOI: 10.3390/su11184830

Jeevan, J., Jyoti, S., 2012. Impact of market orientation on business performance: Role of employee satisfaction and customer satisfaction, Journal of Business Perspective 16(4), 297-313. DOI: 10.1177/0972262912460188

Minta, S., Cempiel, M., 2017. Badanie satysfakcji konsumentów produktu tradycyjnego na przykładzie oscypka, Roczniki Naukowe Stowarzyszenia Ekonomistów Rolnictwa i Agrobiznesu, 6, 177-178. DOI: 10.5604/01.3001.0010.7925

Research Gate, August, https://www.researchgate.net/publication/343674544. DOI: 10.13140/RG.2.2.35180.18569

Turkyilmaz, A., Oztekin, A., Zaim, S., Fahrettin-Demirel, O., 2013. Universal structure modeling approach to customer satisfaction index, Industrial Management and Data System, 113(7), 932-949. DOI: 10.1108/IMDS-12-2012-0444

Wood, L., 2020. Couriers: COVID-19 Couriers See Rise in Residential Demand, Research and Markets, May, https://www.researchandmarkets.com/ issues/couriers-see-risein?utm_source=dynamic\&utm_medium=GNOM

\&utm_code=77q4f3\&utm_campaign=1391536++Couriers+\%26+COVID19\%3a+Hu ge+Increase+in+Residential+Deliveries+as+Customers+Move+to+Online+Shoppin g\&utm_exec=joca220gnomd

Woźniak, J., 2017. Ocena przydatności metod SERVUAL i CSI w kontekście badania logistyki obsługi klienta, Quarterly Journal 2, 242. DOI: 10.19253/reme.2017. 02.020

Woźniak, J., Zimoń, D., 2013. Zastosowanie metody CSI do badania satysfakcji konsumentów na przykładzie wybranej sieci handlowej, Modern Management Review, 23(3), 220. DOI: 10.7862/rz.2016.mmr.37

Xiaohong, L., Xianyi, Z., Yang, X., Ludovic, K., 2008. A fuzzy model of customer satisfaction index in e-commerce, Mathematics and Computers in Simulation, 77, 512-521. DOI: 10.1016/j.matcom.2007.11.017 